University of Montana

ScholarWorks at University of Montana

$7-2014$

\title{
Granivory of invasive, naturalized, and native plants in communities differentially susceptible to invasion
}

\author{
B. M. Connolly \\ Washington State University \\ Dean Pearson \\ University of Montana - Missoula \\ R. N. Mack \\ Washington State University
}

Follow this and additional works at: https://scholarworks.umt.edu/biosci_pubs

Part of the Biodiversity Commons, Biology Commons, and the Ecology and Evolutionary Biology Commons

\section{Let us know how access to this document benefits you.}

\section{Recommended Citation}

B. M. Connolly, D. E. Pearson, and R. N. Mack 2014. Granivory of invasive, naturalized, and native plants in communities differentially susceptible to invasion. Ecology 95:1759-1769. http://dx.doi.org/10.1890/ 13-1774.1

This Article is brought to you for free and open access by the Biological Sciences at ScholarWorks at University of Montana. It has been accepted for inclusion in Biological Sciences Faculty Publications by an authorized administrator of ScholarWorks at University of Montana. For more information, please contact scholarworks@mso.umt.edu. 


\title{
Granivory of invasive, naturalized, and native plants in communities differentially susceptible to invasion
}

\author{
B. M. Connolly, ${ }^{1,3}$ D. E. Pearson, ${ }^{2}$ And R. N. MacK ${ }^{1}$ \\ ${ }^{1}$ School of Biological Sciences, Washington State University, Pullman, Washington 99164 USA \\ ${ }^{2}$ Rocky Mountain Research Station, USDA Forest Service, Missoula, Montana 59801 USA and Division of Biological Sciences, \\ University of Montana, Missoula, Montana 59812 USA
}

\begin{abstract}
Seed predation is an important biotic filter that can influence abundance and spatial distributions of native species through differential effects on recruitment. This filter may also influence the relative abundance of nonnative plants within habitats and the communities' susceptibility to invasion via differences in granivore identity, abundance, and food preference. We evaluated the effect of postdispersal seed predators on the establishment of invasive, naturalized, and native species within and between adjacent forest and steppe communities of eastern Washington, USA that differ in severity of plant invasion. Seed removal from trays placed within guild-specific exclosures revealed that small mammals were the dominant seed predators in both forest and steppe. Seeds of invasive species (Bromus tectorum, Cirsium arvense) were removed significantly less than the seeds of native (Pseudoroegneria spicata, Balsamorhiza sagittata) and naturalized (Secale cereale, Centaurea cyanus) species. Seed predation limited seedling emergence and establishment in both communities in the absence of competition in a pattern reflecting natural plant abundance: $S$. cereale was most suppressed, B. tectorum was least suppressed, and P. spicata was suppressed at an intermediate level. Furthermore, seed predation reduced the residual seed bank for all species. Seed mass correlated with seed removal rates in the forest and their subsequent effects on plant recruitment; larger seeds were removed at higher rates than smaller seeds. Our vegetation surveys indicate higher densities and canopy cover of nonnative species occur in the steppe compared with the forest understory, suggesting the steppe may be more susceptible to invasion. Seed predation alone, however, did not result in significant differences in establishment for any species between these communities, presumably due to similar total small-mammal abundance between communities. Consequently, preferential seed predation by small mammals predicts plant establishment for our test species within these communities but not between them. Accumulating evidence suggests that seed predation can be an important biotic filter affecting plant establishment via differences in consumer preferences and abundance with important ramifications for plant invasions and in situ community assembly.
\end{abstract}

Key words: biotic resistance; eastern Washington, USA; exclosure; forest plant communities; invasibility; invasiveness; recruitment; seed addition; seed bank; seed predation; steppe plant communities.

\section{INTRODUCTION}

The fate of plant immigrants can depend on the extent to which they escape specialist natural enemies, as proposed by the enemy release hypothesis (Keane and Crawley 2002), encounter lethal hazards from the resident biota, as proffered by the biotic resistance hypothesis (Elton 1958), or both. Support for these hypotheses highlights the importance of biotic interactions in determining the fate of plant introductions (Agrawal and Kotanen 2003, Levine et al. 2004, Mitchell et al. 2006, Parker et al. 2006). Most investigations of biotic barriers to plant invasion have focused on

Manuscript received 19 September 2013; revised 23 December 2013; accepted 9 January 2014. Corresponding Editor: T. J. Valone.

${ }^{3}$ E-mail: bconnolly2@wisc.edu competition, parasitism, or grazing (Levine et al. 2004, Parker et al. 2006, Fridley et al. 2007). Recent studies, however, suggest that postdispersal seed predation may also strongly influence the establishment of introduced plants (Reader 1993, Nuñez et al. 2008, Pearson et al. 2011, 2012, 2013, Maron et al. 2012, Allington et al. 2013). Seed predation may have particularly strong effects on introduced plants because many immigrant terrestrial plant populations require seeds for establishment and persistence (Pearson et al. 2013).

In community assembly theory, species that overcome dispersal barriers and abiotic constraints are confronted inevitably by biotic interactions (Weiher and Keddy 1999). Seed predation is an important in situ biotic filter. Within native plant communities seed predators may voraciously consume seeds (Blaney and Kotanen 2001, Mattos et al. 2013), which can suppress plant recruitment (Ostfeld et al. 1997, Bricker and Maron 2012), 
reduce adult plant population densities (Louda 1982, Maron and Kauffman 2006), and drive community composition and species abundance (Brown and Heske 1990). Native generalist seed predators may also influence nonnative species recruitment (Maron et al., 2014) and adult population densities (Pearson et al. 2012, 2013, Allington et al. 2013). Furthermore, postdispersal seed predators may have differential effects on native and nonnative species that could influence invasion outcomes (Maron et al., 2014). For example, seed predators can suppress densities of some exotic plants potentially minimizing their effects on native plants (Allington et al. 2013), whereas other invasive species may gain advantage over natives and naturalized species in part by evading seed predators (Pearson et al. 2011). These studies suggest that seed predation can be an important in situ filter in explaining the relative abundance of nonnative plants. Understanding the role of the seed-predation filter in plant invasions requires examination of seed-predator identity, abundance, and preference in relation to the establishment and abundance of introduced plant species within and between communities.

Different species or guilds of consumers display distinct seed preferences (Kelrick et al. 1986, Reader 1993, Carrillo-Gavilán et al. 2010) that influence plant recruitment. Granivore preference is often related to seed size (Price 1983), although seed size may be a surrogate for more deterministic factors, such as soluble carbohydrate content (Kelrick et al. 1986); seed defense attributes may, however, create exceptions to this pattern (Pearson et al. 2011). Small mammals generally target seeds $>0.50 \mathrm{mg}$ (Reader 1993, Garb et al. 2000, Maron et al. 2012), whereas insects (predominantly ants) often forage for seeds $<0.50 \mathrm{mg}$ (Crist and MacMahon 1992). Birds may display no selectivity based on seed size in some communities (Garb et al. 2000), although grassland birds preferentially consume large seeds in tallgrass prairies (Howe and Brown 1999). Selectivity among seed-predator guilds may create community-specific filters.

Nonnative plant abundance and diversity vary across introduced ranges (Rejmanek et al. 2005). Grazing and seed predation can influence native plant distributions across local and broad geographic and environmental gradients (Louda 1982, Maron and Crone 2006, Orrock et al. 2006) and may similarly affect invasive plants (Lambrinos 2006). Seed removal rates can vary radically among plant communities and along environmental gradients (Christianini and Galetti 2007, Pearson et al. 2013) due to differences in the granivore communities, their abundance, or seed preferences. Consumer abundance, in particular, often differs among habitats, and granivore abundance frequently determines seed removal rates (Ostfeld et al. 1997, Zwolak et al. 2010, Mattos et al. 2013).

Steppe and adjacent coniferous forests in eastern Washington differ strikingly in the abundance of introduced plants. The forests harbor few naturalized or invasive plant species (Daubenmire and Daubenmire 1968, Parks et al. 2005), whereas nonnative grasses and forbs dominate all but a few small remnants of the adjacent native steppe (Daubenmire 1970, Mack 1986). We examined how seed-predator identity, preference, and abundance influence the establishment of naturalized, invasive, and common native species within and between forest and steppe in this region. We predicted that if seed predation were an important filter for plant establishment, it should be inversely related to plant abundance. Consequently, uncommon naturalized species should experience high seed predation and effects on recruitment, followed by intermediate levels of predation on common native species and low levels of predation on invasive species. Furthermore, seed predation should have more detrimental effects on nonnative plant establishment in the less invaded forest compared to the adjacent steppe.

\section{Methods \\ Study sites}

Four sites (1.26-ha each) were established in mature stands of mesic steppe (Festuca idahoensis-Symphoricarpos albus habitat type, sensu Daubenmire 1970); another four sites (1.26-ha each) were established in mature stands of xerophytic coniferous forest (Pinus ponderosa-Symphoricarpos albus habitat type, sensu Daubenmire and Daubenmire 1968). Sites averaged $40.9 \pm 6.1 \mathrm{~km}$ apart (mean \pm SE; UTM site locations, Appendix A). Frequency and percent canopy coverage of nonnative plants were quantified in each stand in the forest understory and the steppe following Daubenmire (1959). Vegetation was sampled in April and May 2011 at each site to account for species differences in phenology.

\section{Field methods}

Identification of postdispersal seed-predator guilds.Seed removal by different granivore guilds was compared in 2011 by evaluating seed removal from trays in four taxa-specific predator exclosures. Each exclosure contained seeds in the bottom of an open plastic petri dish $(15 \mathrm{~cm}$ diameter) that had been buried to ground level. The complete exclosure treatment excluded birds and small mammals with a hardware cloth exclosure (four sides plus top, $30 \times 30 \times 30 \mathrm{~cm}, 1-\mathrm{cm}$ gauge wire) embedded $5 \mathrm{~cm}$ into the mineral soil; insect access was blocked by a $\sim 2.5-\mathrm{cm}$ wide circle of Tanglefoot (Tanglefoot Company, Grand Rapids, Michigan, USA) around the inside rim of the plastic seed tray (Hughes and Westoby 1990). The insect access treatment excluded birds and mammals but allowed insects by installing the complete exclosure without Tanglefoot. The bird/small-mammal access treatment consisted of the complete exclosure with openings $(15 \times 12 \mathrm{~cm})$ in each of the four sides of each exclosure to permit small mammal and bird entry but exclude insects. The small- 
mammal access treatment excluded birds with a cap (50 $\times 50 \mathrm{~cm}$ ) of hardware cloth suspended over the seed tray with metal corner posts $4 \mathrm{~cm}$ above the soil surface; insects were excluded with Tanglefoot by the same method as the bird/small-mammal access treatment.

Seeds of two grass species (native Pseudoroegneria spicata $[3.60 \mathrm{mg} / \mathrm{seed}]$ and naturalized Phalaris canariensis $[7.2 \mathrm{mg} / \mathrm{seed}])$ were offered separately in each exclosure treatment to evaluate the influence of seed type on removal rates by plant community (steppe vs. forest) and granivore guild. At each site, six of each exclosure treatments were randomly assigned to different locations in a $3 \times 8$ grid $(30-\mathrm{m}$ spacing between points). Each exclosure contained $20 \mathrm{~g}$ of one seed type; three replicates of each exclosure treatment were assigned to $P$. spicata or $P$. canariensis. Each seed removal trial was conducted for two consecutive day and night display periods; seeds were collected, air-dried $\left(\sim 25^{\circ} \mathrm{C}, 72 \mathrm{~h}\right)$, and weighed after each display period. This protocol was repeated twice each month in June and September 2011 to correspond with seasonal dehiscence and fluctuations in small-mammal abundance and bird migration.

Quantification of small-mammal seed predators.Small-mammal species composition and abundance were estimated with an annual trapping session at each forest and steppe site in late July to early August from 2010 to 2012. Each trapping grid consisted of 24 pairs (48 total) of Sherman live traps (H. B. Sherman Traps, Tallahassee, Florida, USA) placed $30 \mathrm{~m}$ apart in a $3 \times 8$ grid (sampling area, 1.26 ha). Polypropylene batting served for bedding; traps were covered with a $23 \times 30$ $\mathrm{cm}, 2 \mathrm{~mm}$ thick foam sheet (Foamies, Darice, Strongsville, Ohio, USA) for insulation. Traps were baited with a rolled oats and peanut butter mixture. Each trapping session consisted of four consecutive nights with traps examined twice each day (before 09:00 and after 17:30 hours). Each trapped mammal was identified, ear-tagged with uniquely numbered tags (Stamped Ear Tags [product \#INS1005-1], Kent Scientific Corporation, Torrington, Connecticut, USA), and released at the capture station. The Washington State University Animal Care and Use Committee approved all handling protocols (IACUC \#03959).

In situ preference for native and nonnative seeds.-Seed preference experiments were conducted in 2012 using three native and three nonnative species. Seed trials were conducted in late August corresponding with cessation of seed antithesis for all test species; trials were conducted immediately following the small-mammal trapping sessions (procedure followed Zwolak et al. 2010). We installed 24 seed stations at each site. Each station consisted of the bottom of a single plastic petri dish (15 cm diameter) with 20 seeds of one species mixed with $100 \mathrm{~mL}$ of sand. Dishes were placed at the same grid locations used for trapping. Dishes were randomly assigned seeds of either a native ( $P$. spicata $[3.60 \mathrm{mg} /$ seed] or Balsamorhiza sagittata [10.37 mg/seed]), natu- ralized (Secale cereale [22.62 $\mathrm{mg} / \mathrm{seed}]$ or Centaurea cyanus $[3.32 \mathrm{mg} / \mathrm{seed}]$ ), or invasive plant (Bromus tectorum $[2.67 \mathrm{mg} / \mathrm{seed}]$ or Cirsium arvense $[1.07 \mathrm{mg} /$ seed]). Mature individuals of native species and invasive $B$. tectorum occurred at all sites; adults of the other nonnative test species occurred at some but not all test sites (Appendix B). Appendix C summarizes test-seed source and storage conditions. Seeds were presented for two consecutive days and nights and were examined twice daily (before 07:30 and after 18:00) to differentiate between removal by diurnal (chipmunks, Tamias spp., birds, ants) and nocturnal (deer mice, Peromyscus maniculatus) granivores. Tray contents were collected, counted, and replaced with new sand and seeds during each examination period.

Effects on seedling emergence, establishment, and seed accumulation in the seed bank.-To examine seed predation's influence on plant emergence, establishment, and the subsequent seed bank, we conducted seed addition experiments from 2010 to 2013 by sowing seeds in hardware cloth exclosures (as described in Field methods: Identification of postdispersal seed-predator guilds) that allowed or precluded seed predator access. Twenty-four exclosures were installed at each site in a 3 $\times 8$ grid (30-m spacing between exclosures). Half the exclosures prevented seed-predator access; the other half allowed access through an opening $(15 \times 12 \mathrm{~cm})$ in each side of the exclosure. All living and dead vegetation $<1.5 \mathrm{~m}$ tall was removed in and around each exclosure (0.5-m buffer zone) before seeds were sown to eliminate competition as a confounding factor. Eight exclosures were assigned to each species ( $P$. spicata, $S$. cereale, $B$. tectorum) per site, four with seed predator access and four without. Seeds (100) were sown in each exclosure in early August each year. Emergent seedlings were counted in November. We counted surviving plants the following May to estimate establishment. This experiment was repeated each August by removing live plants and sowing 100 new seeds into the exclosures. All plots were treated with glyphosate herbicide (Roundup, Monsanto, Creve Coeur, Missouri, USA) at the cessation of the study and were monitored through autumn 2013 to ensure no remaining seeds germinated.

We sampled the residual seed bank in each exclosure to determine the remaining density of viable seeds following May plant counts in 2012 and 2013. A soil core $\left(6 \times 5 \mathrm{~cm}, 141 \mathrm{~cm}^{3}\right.$ soil $)$ was taken at the center of each exclosure. Soil core samples were processed through a 2-mm soil sieve; seeds were counted and characterized as viable (i.e., firm, intact endosperm), nonviable, or not filled.

Analysis.-To identify the seed-removing guilds, the percentage seed mass removed from guild-specific seed predator exclosures was averaged for each tray among all trials within site and month. Percentage seed mass removed was then transformed to fit a beta distribution and analyzed using generalized linear mixed models (Proc GLIMMIX; SAS 9.3) where exclosure type, 
community type (steppe or forest), month, seed type, and all interaction combinations were fixed factors; site and tray location within site were random factors.

Small-mammal relative abundance was indexed for each site using the Minimum Number Known Alive (MNKA; Krebs 1966). We calculated total seed predator abundance (TSPA) per site by summing tallies of the three most prevalent granivorous species per community type. We determined if TSPA differed between plant communities using general linear models (Proc GLM, SAS 9.3) including community type as a fixed factor and year as a repeated measure. Seedremoval trays and small-mammal trapping sites were positioned at the same stations within each site to estimate the relationship between small-mammal abundance and seed removal. Using data collected in 2012, we used linear regression (Proc REG, SAS 9.3) to test, by community type, for a relationship between seedpredator abundance at each tray and the number of seeds removed from seed displays.

Seed removal (SR), seedling emergence (EMG), seedling establishment (EST), and viable seed density (VSD) were partitioned by study season (SR, 2012; EMG and EST, 2010-2011, 2011-2012, 2012-2013; VSD, 2011-2012, 2012-2013) and then analyzed with generalized linear mixed models with species class (naturalized, invasive, native), community type, smallmammal access (EMG, EST, VSD only), and all possible interactions between factors as fixed factors. Site and experimental unit location within site were included in this model as random factors. Total seed predator abundance (TSPA) per site was initially included as a potential covariate, but TSPA was never a significant factor (all $P>0.10$ ) and was excluded from final analyses. We also examined the effect of seed mass on seed preference by treating it as a covariate in SR analysis. The relationship between individual seed mass and the number of seeds removed from seed display trays was determined by linear regression. Finally, we evaluated the strength of seed predation on seedling recruitment using the average difference between predator access and exclosures for EMG, EST, and VSD to estimate release from seed predation (Pearson et al. 2011) by site in each year. Release from seed predation was compared using a generalized linear mixed model with species and plant community as fixed factors and site as a random factor.

\section{RESUlts}

\section{Plant community patterns}

Species richness of nonnative plants was greater in the steppe than in the forest understory; nonnative species comprised approximately 24\% (7.00 \pm 1.00 species; mean $\pm \mathrm{SE}$ ) of total species richness in the steppe but only $12 \%$ (3.75 \pm 0.25 species) in the forest (Appendix B). Nonnative species present in both plant communities often had lower frequency and canopy cover in the forest. For example, Bromus tectorum frequency and canopy coverage were $86.0 \% \pm 5.7 \%$ (mean $\pm \mathrm{SE}$ ) and $12.9 \% \pm 3.4 \%$ in the steppe, respectively, versus $19.4 \%$ $\pm 9.7 \%$ and $1.5 \% \pm 0.8 \%$, respectively, in the forest. In the complete exclosures, seedling establishment did not differ between the steppe and forest for $P$. spicata $(t=$ $0.64, \mathrm{df}=84, P=0.522)$, S. cereale $(t=0.62, \mathrm{df}=84, P=$ $0.540)$, or $B$. tectorum $(t=0.69$, df $=84, P=0.495)$, suggesting differences in abiotic conditions between plant communities did not influence seedling establishment for any species.

\section{Identification of postdispersal seed predator guilds}

Small mammals comprised the dominant seed-removing guild (Fig. 1). The mass of seeds removed from insect access treatments never differed from complete exclosures (all $P>0.10$ ). Seed removal from small mammal and bird/small-mammal treatments was greater than seed removal from complete exclosures in both plant communities (all $P<0.05$ ). The extent of seed removal from small-mammal and bird/small-mammal treatments was similar within each treatment in each month in the steppe (June, $t=1.40$, df $=176, P=0.163$; September, $t=$ 1.55 , df $=176, P=0.122$ ), although more seeds were removed from these treatments during autumn than summer (bird/small-mammal treatment in June vs. September, $t=3.27$, df $=173, P=0.001$; small-mammal treatment in June vs. September, $t=3.65$, df $=173, P<$ 0.001). Seed removal did not differ between bird/smallmammal treatments and small-mammal treatments in the forest during summer (bird/small mammal vs. small mammal, $t=1.25, \mathrm{df}=176, P=0.213)$. More seeds were removed, however, from bird/small-mammal treatments than small-mammal treatments in the forest during autumn (bird/small mammal vs. small mammal, $t=2.21$, $\mathrm{df}=176, P=0.028)$. Average seed removal was greater in the forest than the steppe; this difference, however, was not significant $\left(F_{1,6}=4.72, P=0.073\right.$, Appendix D).

$P$. canariensis seeds were much preferred over $P$. spicata seeds, but seed removal varied across exclosures, seasons, and plant communities (Fig. 1; Appendix D). Removal of $P$. canariensis seeds from small-mammal and bird/small-mammal treatments was always greater than removal of $P$. canariensis seeds from complete exclosures (all $P<0.001$ ). Removal of $P$. spicata from smallmammal and bird/small-mammal treatments was greater, however, than its removal from complete exclosures only in the forest and during summer (all $P<0.001$ ).

\section{Quantification of small-mammal seed predators}

Yellow-pine chipmunks (Tamias amoenus), deer mice (Peromyscus maniculatus), and voles (Microtus spp.) were the most abundant granivores in the forest, representing $66.1 \%, 33.1 \%$, and $0.4 \%$ of total captures, respectively. Deer mice, voles, and western harvest mice (Reithrodonomys megalotis) were captured most frequently in the steppe, representing $76.4 \%, 13.8 \%$, and $9.2 \%$ of the total captures, respectively. Other small mammals captured included Sorex sp. $(n=1)$ and Zapus 

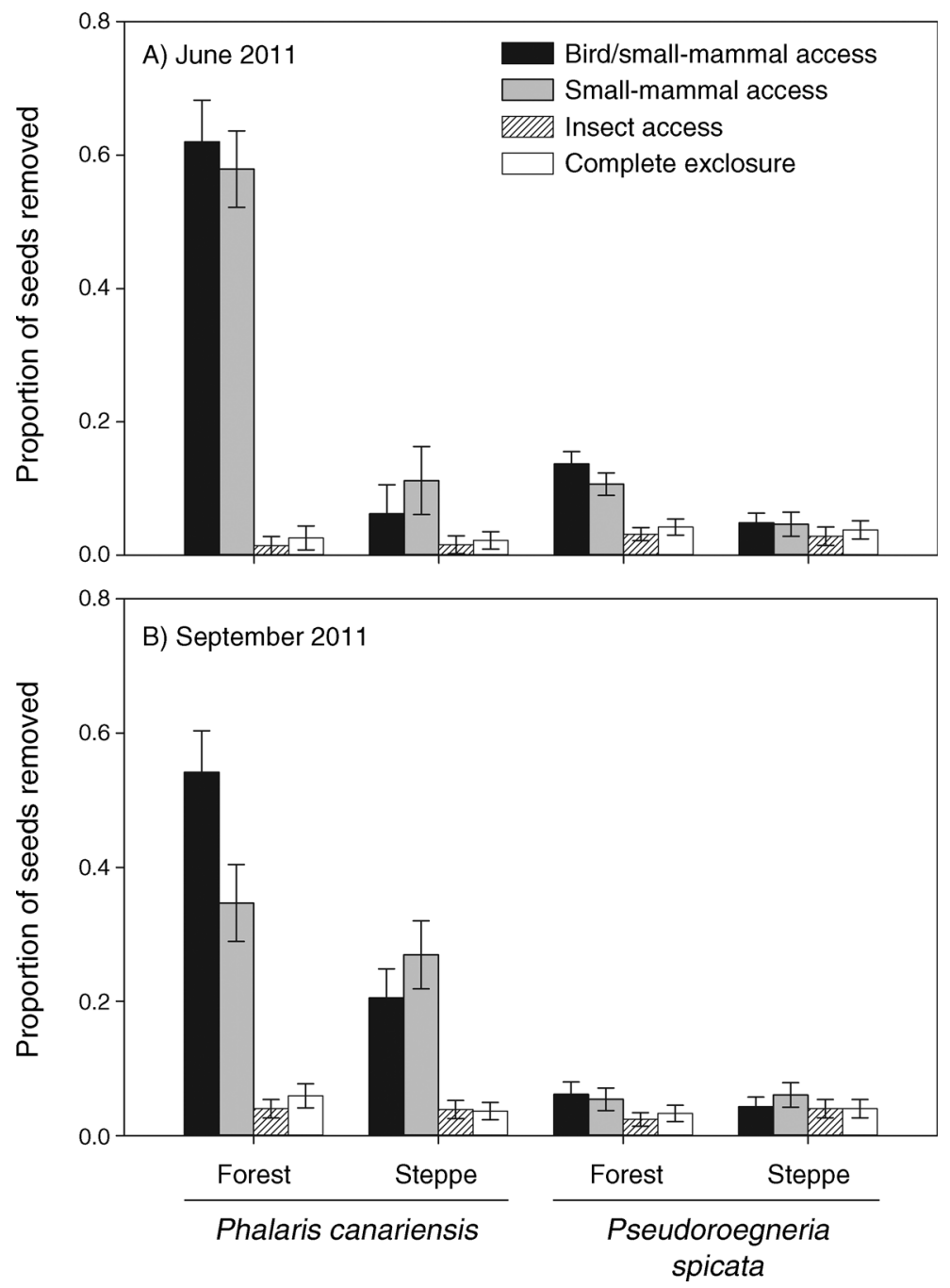

FIG. 1. Proportion of seeds removed (mean \pm SE) for Pseudoroegneria spicata and Phalaris canariensis by predator guilds in eastern Washington steppe and adjacent ponderosa pine forest in (A) June 2011 and (B) September 2011. Four replicated $(n=12)$ exclosure types (complete exclosure, insect access, small-mammal access, and bird/small-mammal access) are averaged for seeds by community type and month.

princeps $(n=4)$; we excluded these incidental species from TSPA analysis. Annual forest TSPA combined $T$. amoenus, P. maniculatus, and Microtus spp. estimates; steppe TSPA combined P. maniculatus, Microtus spp., and $R$. megalotis estimates. Repeated-measures analysis indicated no significant difference in TSPA by plant community $\left(F_{1,6}=0.37, P=0.567\right)$ but indicated significant variation by year $\left(F_{2,12}=6.58, P=0.012\right)$. TSPA was similar in 2010 and $2012\left(F_{1,6}=0.04, P=\right.$ $0.851)$ but was lower in 2011 than in either $2010\left(F_{l, 6}=\right.$ 29.28, $P=0.002)$ or $2012\left(F_{1,6}=8.63, P=0.026\right.$; Appendix E).

\section{Effects on seed availability, seedling emergence and establishment, and seed bank size}

Seed removal differed by seed class $\left(F_{2,118}=7.23, P=\right.$ 0.001 ); fewer seeds of invasive species were removed than seeds of either naturalized or native species (all $P<$ $0.001)$. The number of seeds of native and naturalized species removed did not differ $(t=0.88, \mathrm{df}=159, P=$ 0.381 ). Seedling emergence and establishment were greater for all species in every year when small mammals were excluded (Fig. 2; Appendix F). The influence of predator release on seedling emergence and establishment differed by species (emergence, $F_{2,59}=4.31, P=$ 0.018; establishment, $F_{2,58}=5.14, P=0.009$ ), although the magnitude of release was similar among species. Seedling establishment in all years and seedling emergence in 2012-2013 were affected by interactions between species and small-mammal access (Appendix F). Naturalized $S$. cereale was most strongly released from predation by the exclosures; predator release for $S$. cereale seedling emergence and establishment were greater than occurred for $B$. tectorum (emergence, $t=$ 

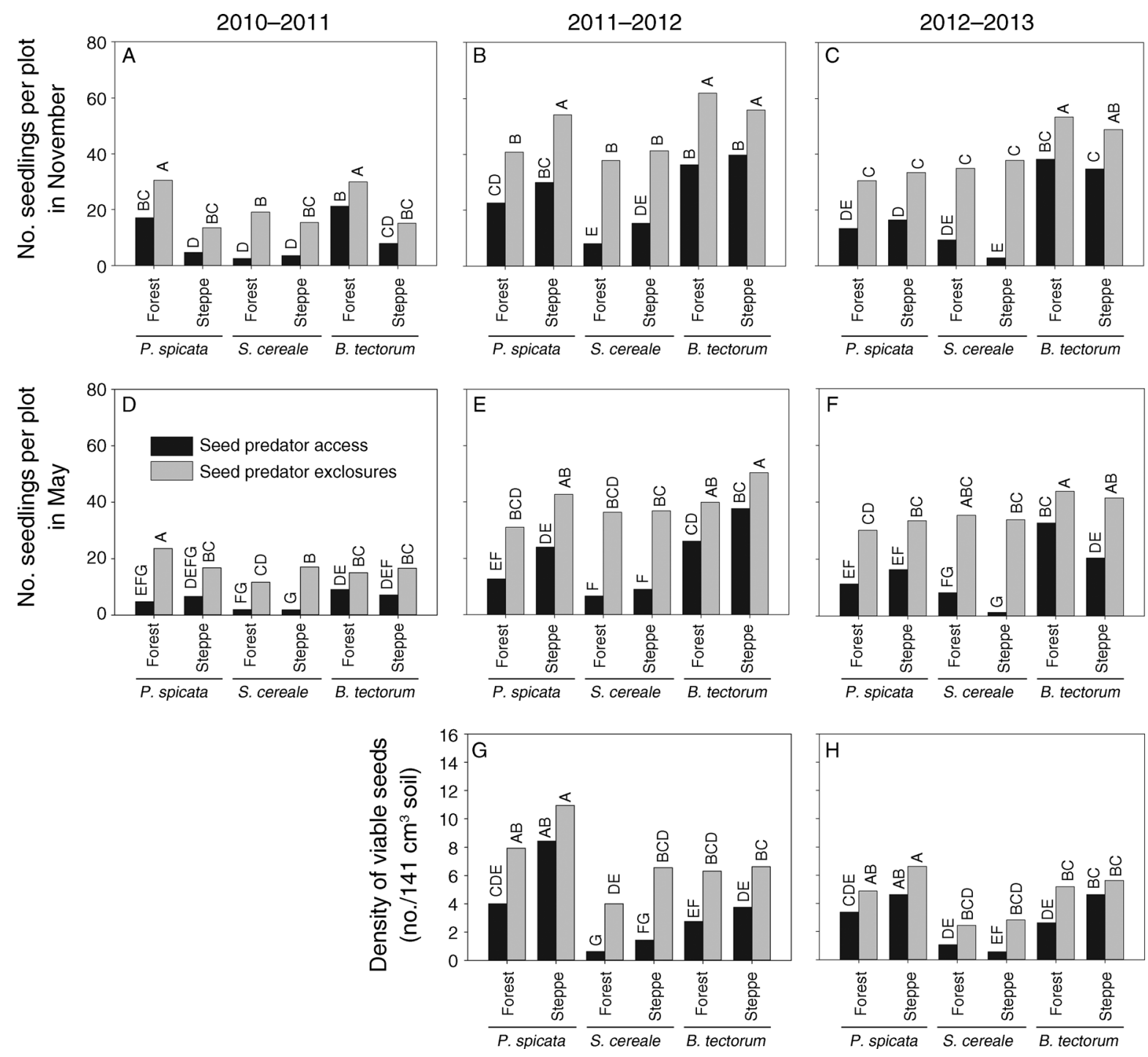

FIG. 2. Effect of seed predator exclosure on the (A-C) emergence, (D, F) establishment, and (G, H) viable seed bank for Pseudoroegneria spicata, Secale cereale, and B. tectorum in steppe and forest, 2010-2011, 2011-2012, and 2012-2013. Multiple comparison tests were conducted with the Tukey HSD method; different uppercase letters indicate significant differences at a Type I error $=0.05$.

2.73, $\mathrm{df}=59, P=0.008$; establishment, $t=3.56, \mathrm{df}=60$, $P<0.001$ ) and $P$. spicata (emergence, $t=2.25, \mathrm{df}=59, P$ $=0.028$; establishment, $t=2.15, \mathrm{df}=60, P=0.036)$ when compared across all years. $P$. spicata emergence and establishment tended to be more affected by predator release than invasive $B$. tectorum, but these differences were not significant (emergence, $t=1.50$, df $=59, P=$ 0.606; establishment, $t=1.34$, $\mathrm{df}=60, P=0.183$ ).

Predator access resulted in fewer viable seeds in residual seed banks vs. the residual seed bank in exclosures (Fig. 2; Appendix F). The density of viable seeds remaining within the seed bank varied by species (Appendix F); fewer $S$. cereale seeds remained than the seeds of $B$. tectorum or $P$. spicata (all $P<0.001$ ). Fewer $B$. tectorum seeds remained vs. seeds of $P$. spicata in $2012(t=4.09, \mathrm{df}=174, P<0.001)$ but not in $2013(t=$ 1.04, df $=174, P=0.299)$. We found significant interaction between species and predator access in both years (Appendix F), suggesting that predation had a greater effect on the seed bank of some species than others.

Seed mass explained much of the variation attributable to seed removal. In the forest, the number of seeds removed was strongly, positively correlated with larger individual seed mass (Fig. 3A; $\beta=0.258, F_{1,6}=10.70, r^{2}$ $=0.728, P=0.032$ ). In the steppe, seed removal tended to increase with seed mass, but the relationship was not significant (Fig. 3B; $\beta=0.164, F_{1,6}=1.87, r^{2}=0.318, P=$ $0.244)$. 

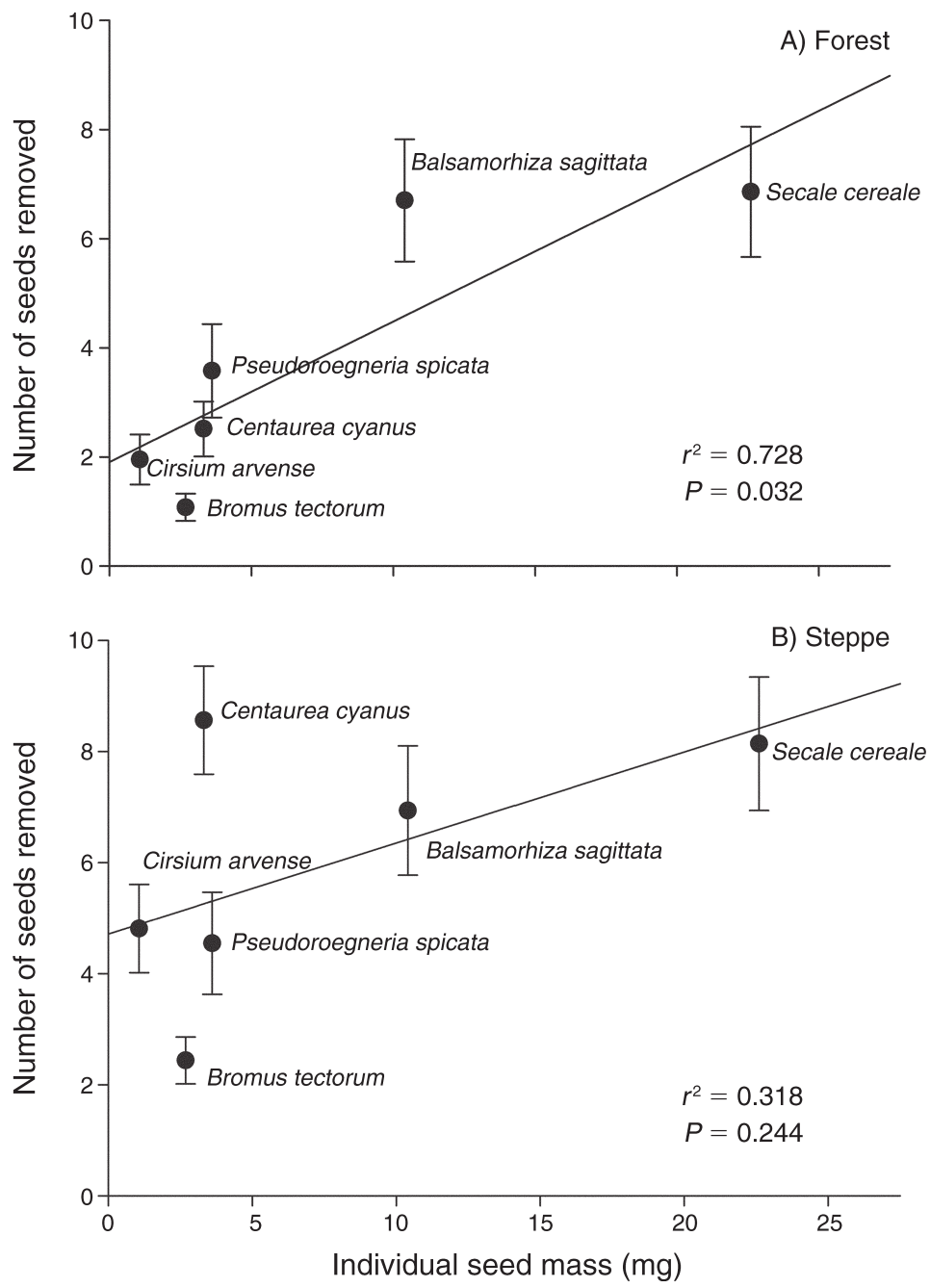

FIG. 3. Relationship between individual seed mass and number of seeds removed from display trays in (A) forest and (B) steppe in autumn 2012. The solid line indicates the predicted linear regression fit; inset values report model fit $\left(r^{2}\right)$ value and linear regression model fit probability.

\section{The effect of seed predation on plant community susceptibility to plant invasion}

Small-mammal abundance in 2012 correlated with seed removal rates in the steppe (Appendix $\mathrm{G} ; \beta=0.809$, $\left.F_{1,7}=13.02, P=0.011\right)$ but not in the forest $(\beta=-0.055$, $\left.F_{1,8}=0.01, P=0.959\right)$. However, variability in seed predator abundance was low in the forest (Appendix E). Seed removal rates did not differ by plant community $\left(F_{1,5}=2.96, P=0.144\right)$; the community type by species interaction was marginally significant $\left(F_{2,119}=3.01, P=\right.$ 0.053). Low seed removal rates for $B$. tectorum and $C$. arvense in the forest drove this pattern; fewer seeds were removed from this community type and species combination than from any other treatment. Community type had no effect on the interaction between species and small-mammal access for emergence, but establishment during the 2010-2011 growing season correlated with community type (Appendix F). During 2010-2011, both
B. tectorum and P. spicata had lower establishment in predator access treatments than exclosures; $B$. tectorum establishment was lower in the steppe, whereas $P$. spicata establishment was lower in the forest (Appendix F). Predator release on seedling emergence and establishment, however, did not vary between community types (emergence, $F_{1,6}=0.61, P=0.466$; establishment, $F_{2,59}=0.96, P=0.391$ ) or in seed type by community type interactions (emergence, $F_{1,6}=0.61, P=0.466$; establishment, $F_{2,58}=0.48, P=0.624$ ) across all years. More viable seeds remained in the steppe seed bank than in the forest seed bank in 2012 but not in 2013 (Appendix F). A significant three-way interaction between seed type, community type, and small-mammal access in 2013 for viable-seed density (Appendix F) was primarily a consequence of more $B$. tectorum seeds being removed from seed banks in the forest than in the steppe (Fig. $2 \mathrm{H} ; t=1.76, \mathrm{df}=12, P=0.105$ ). The extent of predator release on the density of viable seeds in the seed 
bank was not dependent on community type $\left(F_{1,6}=0.02\right.$, $P=0.893)$ or species by community type interactions $\left(F_{1,6}=0.61, P=0.466\right)$.

\section{DisCUSSION}

In examining the effects of postdispersal seed predation on invasive, naturalized, and native plants in a Pacific Northwest forest and steppe, we found that small mammals were the primary seed predators in both communities. Small-mammal seed removal for our six test species was much stronger for naturalized and native species than for invasive species, with seed mass strongly predicting seed removal. Seed addition experiments with three of these species indicated that seed predation reduced emergence, establishment, and seed bank size for each species; establishment of the naturalized $S$. cereale was most strongly suppressed and invasive $B$. tectorum was least suppressed in both plant communities. Our vegetation surveys confirmed that patterns of seed predator impacts were consistent with relative abundances of the test species in these communities. Vegetation surveys also verified that the steppe had higher richness and percent cover of nonnative plants than adjacent forests. Seed addition experiments, however, indicated that recruitment of test species was similar between habitats with and without seed predator access to seeds. Consequently, the patterns of seed predation and seed predator effects on plant recruitment that we observed support a hypothesis that seed predation can influence plant invasion via consumer preference. But the differences in apparent susceptibility of the two plant communities to invasion cannot be explained by seed predation, a result likely attributable to overall similarity in seed predator preference and abundance between these communities.

Different seed predator guilds can have distinctly different effects on plant recruitment (Brown and Heske 1990). Our results indicated that small mammals were the primary seed predators in these communities; granivorous birds contribute somewhat to seed removal in the forest. Small mammals may be more abundant, less seasonally limited, or more efficient seed predators than granivorous birds and ants in these communities. We did not compare relative abundance among granivore guilds, but invertebrates and birds in temperate ecosystems have only seasonal access to seeds because invertebrates become inactive and many species of seedeating birds migrate to lower latitudes during cooler months. In contrast, most granivorous small mammals in this region remain active year-round (Pyke 1986). Additionally, small mammals may forage more intensively due to high energetic demands (Parmenter et al. 1984) or may forage more efficiently (Garb et al. 2000). Seed removal by invertebrates was not apparent, suggesting invertebrate seed predators were not abundant. Birds removed seeds only in the forest during autumn, suggesting that the food preferences of some birds may shift seasonally toward seeds or that migratory birds may contribute to seed removal.

Seed removal rates and their effects in reducing plant establishment were strongest for naturalized and native species and weakest for invasive species. Although rodent seed predators can disperse seeds through caching (Vander Wall et al. 2005), we saw no evidence of seed caches germinating over the three years of the study. Additionally, our seed removal results correlate strongly with plant recruitment results from seedaddition experiments and our surveys of natural plant abundance, suggesting seed removal largely equates to seed destruction. Naturalized $S$. cereale was extirpated in $41 \%$ of small-mammal access treatments, with low survival in the remaining predator access treatments (Fig. 2). Consistent with this result, field surveys indicate $S$. cereale was rare within the steppe and absent in the forest (Appendix B), despite its frequent occurrence in nearby cultivated fields (Gaines and Swan 1972). In contrast, seed predation had weak effects on the establishment of invasive B. tectorum (Fig. 2), the most abundant nonnative plant in the steppe and forest (Appendix B). Seeds of native $P$. spicata experienced an intermediate rate of removal (Fig. 3) and recruitment limitation (Fig. 2) but developed the largest seed bank of the three species. The high density of $P$. spicata seeds in the seed bank may compensate for seed loss due to predation.

Seed mass was strongly correlated with seed removal rates and their effects on plant recruitment (Fig. 3A, B), a result consistent with expectations for small-mammal seed predators (Reader 1993, Pearson et al. 2011, Maron et al. 2012, but see Carrillo-Galiván et al. 2010). This result suggests that seed mass or other seed traits indicative of consumer seed preference might help predict invasion outcomes where seed predation is an important biotic filter. Although we selected our species to be representative of different invasion classes without regard to seed mass, seed mass was completely correlated with invasion class, preventing us from discerning the role of seed mass in affecting invader status. Nonetheless, the few long-term studies examining seed removal effects on nonnative species establishment and adult-plant abundance show that small-mammal seed predators are capable of suppressing some largeseeded species below their potential to become invasive (Pearson et al. 2012, Allington et al. 2013), whereas many invasive species with small or defended seeds may evade this important filter (Pearson et al. 2011, Maron et al. 2012). Plants with larger seeds are often superior competitors during early life stages (Reader 1993, Turnbull et al. 1999, Maron et al. 2012), consequently, large-seeded species with chemical or physical defenses may gain a distinct advantage in establishment by obviating the tradeoffs between competition and predation (Pearson et al. 2011, Maron et al. 2012). Additionally, native species may be more constrained by seed size-seed number trade-offs than are nonnative species 
(Mason et al. 2008), suggesting seed predators favoring large seeds may have greater impacts on native than nonnative species.

Seed size largely explained patterns of seed removal and plant recruitment, but did not fully explain the substantial seed predator avoidance of B. tectorum. $C$. arvense has the smallest seed mass of our test species, potentially explaining its low seed removal. B. tectorum, however, was removed significantly less $(\sim 50 \%)$ than $C$. arvense in both plant communities, despite its seed mass being much greater than the seeds of $C$. arvense (Fig. $3 \mathrm{~A}, \mathrm{~B})$. Invasive plants may have novel seed defenses (e.g., secondary chemicals, mechanical defense) or lower nutritional value that deter seed predators, resulting in their seeds' lower rates of removal compared to the seeds of co-occurring natives and naturalized plants (Kelrick et al. 1986, Pearson et al. 2011). The long, persistent awn on the B. tectorum caryopsis could increase seedhandling time, thereby reducing its value to seed predators. Additionally, the relatively low caloric and high structural carbohydrate content of these seeds may further reduce their food value (Kelrick et al. 1986).

Seed removal is a short-term evaluation of seed predator influence, especially as granivores' effects on plant abundance may be delayed (Guo et al. 1995). Long-term effects of seed predation, however, may be compounded or moderated depending on how they affect the seed bank (Maron and Gardner 2000, Maron and Kauffman 2006). Although predator removal similarly affected the density of viable seeds within the seed bank among the three test species, B. tectorum and $S$. cereale had smaller residual seed banks. Consequently, a greater proportion of the nonnative seed bank was affected by seed predation compared with the $P$. spicata seed bank. Seed predation resulted in $77 \%$ and $42 \%$ fewer viable $S$. cereale and $B$. tectorum seeds remaining in the seed bank, respectively, whereas $P$. spicata seed banks were $33 \%$ lower in predator access treatments compared to exclosures. Persistent seed banks may facilitate recruitment among nonnative plants (Richardson and Kluge 2008), but postdispersal seed predation can alter long-term plant abundance by reducing the input to these seed banks (Maron and Kauffman 2006). Removal of nonnative seeds from the seed bank may generate seed limitation and limit seedling recruitment.

At the community level, our surveys confirmed that nonnative species were more prominent in the steppe compared to the forest understory, a long-term consistent pattern (Daubenmire and Daubenmire 1968, Daubenmire 1970). We found that the establishment counts of $B$. tectorum and $S$. cereale were similar between forest and the steppe when propagule pressure was held constant and plant competitors and seed predators were excluded, suggesting that abiotic factors were not responsible for these differences. We quantified greater removal of nonnative $P$. canariensis in the forest than in the steppe. Predator effects were also greater for the seed banks of invasive $B$. tectorum in forest than in steppe, suggesting that seed predation on nonnative species may be somewhat greater in the forest. Overall seed predation did not, however, produce differences in nonnative plant establishment between forest and steppe. The lack of differences between plant communities in the effects of seed predation on recruitment was likely due to the lack of difference in total granivore abundance between these community types (Appendix E). Seed removal was strongly correlated with smallmammal abundance in the steppe, where it explained $63 \%$ of the variance in seed removal (variation in smallmammal abundance was too small to determine any relationship in the forest). Although the composition of the small-mammal granivore guild are somewhat different between forest and steppe, these differences did not change overall seed preferences between community types. Differences in propagule pressure or other aspects of biotic resistance may explain instead the observed difference in susceptibility of these plant communities to invasion. For example, B. tectorum has higher seedling emergence and percent survivorship following disturbance of the Pinus ponderosa understory compared to undisturbed controls (Pierson and Mack 1990), indicating competition is a barrier to its establishment.

Accumulating evidence suggests that seed predation can substantially affect nonnative plant establishment and abundance (Reader 1993, Nuñez et al. 2008, Pearson et al. 2011, 2012, 2013, Maron et al. 2012, Allington et al. 2013). Our results provide detailed, experimentally derived evidence that differential seed predation contributes to the varying fates of some introduced plants within and possibly between systems. Moreover, evaluating seed traits (e.g., seed mass) in the context of consumer preferences may help to predict such outcomes (Pearson et al. 2011). Further manipulative field experimentation of seed predation across a broad spectrum of communities will clarify the role of this important in situ filter in both terrestrial plant invasions and community assembly.

\section{Acknowledgments}

We thank J. L. Maron and two anonymous reviewers for helpful comments regarding the manuscript and J. L. Orrock for helpful advice on experimental design. We thank D. J. Connolly and J. L. Richards for assistance with exclosure construction. We thank Y. K. Ortega for consultations regarding statistical analysis. We thank $\mathrm{M}$. Rule for assistance with site identification and permit preparation at the Turnbull National Wildlife Refuge. The Betty Higginbotham trust, John W. Marr Memorial trust fund, Washington Native Plant Society (WNPS) Research Grant, and WNPS-NE chapter provided funding to support this work.

\section{Literature Cited}

Agrawal, A. A., and P. M. Kotanen. 2003. Herbivores and the success of exotic plants: a phylogenetically controlled experiment. Ecology Letters 6:712-715.

Allington, G. R., D. N. Koons, S. K. Morgan Ernest, M. R. Schutzenhofer, and T. J. Valone. 2013. Niche opportunities and invasion dynamics in a desert annual community. Ecology Letters 16:158-166. 
Blaney, C. S., and P. M. Kotanen. 2001. Post-dispersal losses to seed predators: an experimental comparison of native and exotic old field plants. Canadian Journal of Botany 79:284292.

Bricker, M., and J. L. Maron. 2012. Postdispersal seed predation limits the abundance of a long-lived perennial forb (Lithospermum ruderale). Ecology 93:532-543.

Brown, J. H., and E. J. Heske. 1990. Control of a desertgrassland transition by a keystone rodent guild. Science 250 : 1705-1707.

Carrillo-Gavilán, M. A., H. Lalagüe, and M. Vilà. 2010. Comparing seed removal of 16 pine species differing in invasiveness. Biological Invasions 12:2233-2242.

Christianini, A. V., and M. Galetti. 2007. Spatial variation in post-dispersal seed removal in an Atlantic forest: effects of habitat, location and guilds of seed predators. Acta Oecologica 32:328-336.

Crist, T. O., and J. A. MacMahon. 1992. Harvester ant foraging and shrub-steppe seeds: interactions of seed resources and seed use. Ecology 73:1768-1779.

Daubenmire, R. 1959. A canopy-coverage method of vegetational analysis. Northwest Science 33:43-64.

Daubenmire, R. 1970. Steppe vegetation of Washington. Washington Agricultural Experiment Station Tech Bulletin 62:1-131.

Daubenmire, R., and J. Daubenmire. 1968. Forest vegetation of eastern Washington and northern Idaho. Washington Agricultural Experiment Station Tech Bulletin 60:1-104.

Elton, C. 1958. The ecology of invasions by animals and plants. University of Chicago Press, Chicago, Illinois, USA.

Fridley, J. D., J. J. Stachowicz, S. Naeem, D. F. Sax, E. W. Seabloom, M. D. Smith, T. J. Stohlgren, D. Tilman, and B. Von Holle. 2007. The invasion paradox: reconciling pattern and process in species invasions. Ecology 88:3-17.

Gaines, X. M., and D. G. Swan. 1972. Weeds of eastern Washington and adjacent areas. C. W. Hill Press, Spokane, Washington, USA.

Garb, J., B. P. Kotler, and J. S. Brown. 2000. Foraging and community consequences of seed size for coexisting Negev desert granivores. Oikos 88:291-300.

Guo, Q., D. B. Thompson, T. J. Valone, and J. H. Brown. 1995. The effects of vertebrate granivores and folivores on plant community structure in the Chihuahuan desert. Oikos 73: 251-259.

Howe, H. F., and J. S. Brown. 1999. Effects of birds and rodents on synthetic tallgrass communities. Ecology 80:17761781.

Hughes, L., and M. Westoby. 1990. Removal rates of seeds adapted for dispersal by ants. Ecology 71:138-148.

Keane, R. M., and M. J. Crawley. 2002. Exotic plant invasions and the enemy release hypothesis. Trends in Ecology and Evolution 17:164-170.

Kelrick, M. J., J. A. MacMahon, R. R. Parmenter, and D. V. Sisson. 1986. Native seed preferences of shrub-steppe rodents, birds and ants: the relationships of seed attributes and seed use. Oecologia 68:327-337.

Krebs, C. J. 1966. Demographic changes in fluctuating populations of Microtus californicus. Ecological Monographs $36: 239-273$

Lambrinos, J. G. 2006. Spatially variable propagule pressure and herbivory influence invasion of chaparral shrubland by an exotic grass. Oecologia 147:327-334.

Levine, J. M., P. B. Adler, and S. G. Yelenik. 2004. A metaanalysis of biotic resistance to exotic plant invasions. Ecology Letters 7:975-989.

Louda, S. M. 1982. Distribution ecology: variation in plant recruitment over a gradient in relation to insect seed predation. Ecological Monographs 52:25-41.

Mack, R. N. 1986. Alien plant invasion into the Intermountain West: a case history. Pages $192-213$ in H. A. Mooney and J. Drake, editors. Ecology of biological invasions of North
America and Hawaii. Springer-Verlag, New York, New York, USA.

Maron, J. L., H. Auge, D. E. Pearson, L. Korell, I. Hensen, K. N. Suding, and C. Stein. 2014. Staged invasions across disparate grasslands: effects of seed provenance, consumers, and disturbance on productivity and species richness. Ecology Letters 17:499-507.

Maron, J. L., and E. Crone. 2006. Herbivory: effects on plant abundance, distribution and population growth. Proceedings of the Royal Society B 273:2575-2584.

Maron, J. L., and S. N. Gardner. 2000. Consumer pressure, seed versus safe-site limitation, and plant population dynamics. Oecologia 124:260-269.

Maron, J. L., and M. J. Kauffman. 2006. Habitat-specific impacts of multiple consumers on plant population dynamics. Ecology 87:113-124.

Maron, J. L., D. E. Pearson, T. Potter, and Y. K. Ortega. 2012. Seed size and provenance mediate the joint effects of disturbance and seed predation on community assembly. Journal of Ecology 100:1492-1500.

Mason, R. A. B., J. Cooke, A. T. Moles, and M. R. Leishman. 2008. Reproductive output of invasive versus native plants. Global Ecology and Biogeography 17:633-640.

Mattos, K. J., J. L. Orrock, and J. I. Watling. 2013. Rodent granivores generate context-specific seed removal in invaded and uninvaded habitats. American Midland Naturalist 169: 168-178.

Mitchell, C. E., et al. 2006. Biotic interactions and plant invasions. Ecology Letters 9:726-740.

Nuñez, M. A., D. Simberloff, and M. A. Relva. 2008. Seed predation as a barrier to alien conifer invasions. Biological Invasions 10:1389-1398.

Orrock, J. L., D. J. Levey, B. J. Danielson, and E. I. Damschen. 2006. Seed predation, not seed dispersal, explains the landscape-level abundance of an early-successional plant. Journal of Ecology 94:838-845.

Ostfeld, R. S., R. H. Manson, and C. D. Canham. 1997. Effects of rodents on survival of tree seeds and seedling invading old fields. Ecology 78:1531-1542.

Parker, J. D., D. E. Burkepile, and M. E. Hay. 2006. Opposing effects of native and exotic herbivores on plant invasions. Science 311:1459-1461.

Parks, C., S. Radosevich, B. Endress, B. Naylor, D. Anzinger, L. Rew, B. Maxwell, and K. Dwire. 2005. Natural and landuse history of the Northwest mountain ecoregions (USA) in relation to patterns of plant invasions. Perspectives in Plant Ecology, Evolution and Systematics 7:137-158.

Parmenter, R. R., J. A. MacMahon, and S. B. Vander Wall. 1984. The measurement of granivory by desert rodents, birds and ants: a comparison of an energetics approach and a seeddish technique. Journal of Arid Environments 7:75-92.

Pearson, D. E., R. M. Callaway, and J. L. Maron. 2011. Biotic resistance via granivory: establishment by invasive, naturalized, and native asters reflects generalist preference. Ecology 92:1748-1757.

Pearson, D. E., J. L. Hierro, M. Chiuffo, and D. Villarreal. 2014. Rodent seed predation as a biotic filter influencing exotic plant abundance and distribution. Biological Invasions 16:1185-1196.

Pearson, D. E., T. Potter, and J. L. Maron. 2012. Biotic resistance: exclusion of native consumers releases populations of a weak invader. Journal of Ecology 100:1383-1390.

Pierson, E. A., and R. N. Mack. 1990. The population biology of Bromus tectorum in forests: effect of disturbance, grazing, and litter on seedling establishment and reproduction. Oecologia 84:526-533.

Price, M. V. 1983. Laboratory studies of seed size and seed species selection by heteromyid rodents. Oecologia 60:259263.

Pyke, D. A. 1986. Demographic responses of Bromus tectorum and seedlings of Agropyron Spicatum to grazing by small 
mammals: occurrence and severity of grazing. Journal of Ecology 74:739-754.

Reader, R. J. 1993. Control of seedling emergence by ground cover and seed predation in relation to seed size for some oldfield species. Journal of Ecology 81:169-175.

Rejmanek, M., D. M. Richardson, and P. Pysek. 2005. Plant invasions and invasibility of plant communities. Pages 332 355 in E. van der Maarel, editor. Vegetation ecology. Blackwell, Oxford, UK.

Richardson, D. M., and R. L. Kluge. 2008. Seed banks of invasive Australian Acacia species in South Africa: role in invasiveness and options for management. Perspectives in Plant Ecology, Evolution and Systematics 10:161-177.
Turnbull, L. A., M. Rees, and M. J. Crawley. 1999. Seed mass and the competition/colonization trade-off: a sowing experiment. Journal of Ecology 87:899-912.

Vander Wall, S. B., K. M. Kuhn, and M. J. Beck. 2005. Seed removal, seed predation, and secondary dispersal. Ecology 86:801-806.

Weiher, E., and P. Keddy. 1999. Assembly rules as general constraints on community composition. Pages 251-271 in E. Weiher and P. Keddy, editors. Ecological assembly rules: perspectives, advances, retreats. Cambridge University Press, New York, New York, USA.

Zwolak, R., D. E. Pearson, Y. K. Ortega, and E. E. Crone 2010. Fire and mice: seed predation moderates fire's influence on conifer recruitment. Ecology 91:1124-1131.

\section{Supplemental Material}

Appendix A

Study sites with UTM coordinates (Ecological Archives E095-155-A1).

Appendix B

A table summarizing nonnative plant coverage and frequency by community (Ecological Archives E095-155-A2).

\section{Appendix C}

A table summarizing test-seed source and storage conditions (Ecological Archives E095-155-A3).

\section{Appendix D}

A table summarizing results from generalized linear mixed model analysis of seed predator identification study (Ecological Archives E095-155-A4).

\section{Appendix E}

A graph summarizing total seed-predator abundance (TSPA), 2010-2012 (Ecological Archives E095-155-A5).

\section{Appendix F}

A table summarizing results from generalized linear mixed model analysis of seed recruitment study (Ecological Archives E095-155-A6).

\section{Appendix G}

A graph showing the correlation between small-mammal abundance and seed removal rates in the steppe in 2012 (Ecological Archives E095-155-A7). 